\title{
PERLUASAN KEWENANGAN KOMISI YUDISIAL DALAM RANGKA PEMBERANTASAN PRAKTIK MAFIA PERADILAN
}

\author{
Oleh : \\ Andi Samsuduha* \\ Ibrahim*
}

ABSTRAK

Lahirnya Komisi Yudisial dilatar-belakangi oleh kuatnya keinginan rakyat, yang disuarakan melalui gerakan reformasi untuk membersihkan hakim dan badan-badan dari praktik mafia peradilan. Karena praktik-praktik mafia peradilan tersebut, sudah menggurita dan bersifat sistemik, maka pembersihannya tidak mungkin lagi dilakukan oleh mekanisme pengawasan internal dengan cara-cara yang konvensional. Diperlukan cara pemberantasan yang bersifat "luar biasa", yang hanya bisa dilakukan oleh sebuah lembaga pengawasan eksternal yang bersifat independen dan kredibel. Dengan demikian, jelaslah kiranya, betapa strategisnya amanat Konstitusi yang diletakkan di pundak Komisi Yudisial. Pemberantasan mafia peradilan, merupakan titik pangkal yang paling menentukan kualitas penegakan hukum, terutama penegakan hukum pidana.

Kata Kunci: Komisi Yudisial, Pemberantasan, Mafia Peradilan

\section{A. Latar Belakang Masalah}

Pembahasan mengenai Komisi Yudisial, kiranya tidak dapat dipisahkan dari gerakan reformasi yang terjadi pada tahun 1998, dimana tuntutan utamanya adalah terciptanya proses demokratisasi dalam penyelenggaraan sistem ketatanegaraan dan terbentuknya masyarakat madani (civil society) dimana di dalamnya hak-hak warga negara dalam segala lapangan kehidupan berbangsa dan bernegara, dihormati dan dimuliakan.

Salah satu perwujudan dari proses demokratisasi dalam penyelenggaraan sistem ketatanegaraan, adalah reformasi menyeluruh di bidang peradilan. Reformasi peradilan, adalah bagian dari reformasi kehidupan ketatanegaraan sebagai hasil dari gerakan moral rakyat terhadap penguasa Orde Baru yang otoriter dan antidemokrasi.

Ciri pokok dari kekuasaan ini adalah dijalankannya kekuasaan dengan sentralistik, anti demokrasi, kontrol yang ketat terhadap semua lembaga negara, partai politik dan organisasi masyarakat, serta tidak transparan. Dalam situasi demikian,

\footnotetext{
* PNS di Pemkab Ma. Jambi, Alumni Program Magister Ilmu Hukum Unbari.

* Pengajar Program Magister Ilmu Hukum Unbari.
} 
korupsi memperoleh lahan yang subur. Proses peradilan dalam penegakan hukum dan keadilan sepenuhnya di bawah pengaruh kekuasaan.

Dewasa ini, setelah reformasi, semua tatanan kehidupan politik, sosial ekonomi dan hukum diletakkan dalam paradigma baru yang didasarkan kepada cita-cita kemerdekaan dan ciri negara sebagai sebuah negara hukum sebagaimana amanat Undang-Undang Dasar Negara Republik Indonesia Tahun 1945 (Undang-Undang Dasar 1945), dengan memperhatikan dan merespon tuntutan keadilan di segala bidang yakni keadilan di bidang hukum, politik, sosial, ekonomi, pendidikan, lingkungan, keamanan dan budaya.

Undang-Undang Dasar 1945 secara tegas menyatakan bahwa Negara Indonesia berdasarkan atas hukum (rechtsstaat), tidak berdasarkan atas kekuasaan belaka (machtsstaat). Hal itu berarti bahwa Negara Republik Indonesia ialah negara hukum yang demokratis berdasarkan Pancasila dan Undang-Undang Dasar 1945, menjunjung tinggi hak asasi manusia dan menjamin segala warganegara bersamaan kedudukannya di dalam hukum dan pemerintahan, serta wajib menjunjung tinggi hukum dan pemerintahan itu dengan tidak ada kecualinya.

Salah satu prinsip penting negara yang yang bersifat rechtsstaat adalah adanya jaminan penyelengaraan kekuasaan kehakiman yang merdeka, bebas dari pengaruh kekuasaan lainnya, untuk menyelenggarakan peradilan guna menegakkan hukum dan keadilan dengan selurus-lurusnya.

Dengan demikian, secara konstitusional kekuasaan kehakiman, memiliki peran yang penting dan menempati posisi yang sangat strategis dalam menjamin tegaknya hukum dan keadilan. Melalui lembaga peradilanlah, aturan-aturan hukum berupa Undang-Undang negara dilaksanakan dan diawasi pelaksanaannya. Disamping itu, kepada peradilan pulalah, setiap warga negara menambatkan harapannya, agar ia memperoleh kepastian hukum, kebenaran, keadilan dan kemamfaatan dari penerapan aturan-aturan hukum tersebut terhadap dirinya.

Mengingat pentingnya peran dan posisi lembaga peradilan dan besarnya harapan masyarakat untuk memperoleh kebenaran dan kepastian hukum melalui lembaga peradilan, maka sangat diperlukan pengawasan terhadap lembaga peradilan sedemikian rupa sehingga kekuasaan kehakiman yang merdeka dan bebas dari pengaruh kekuasaan lainnya itu benar-benar dipergunakan untuk menciptakan kebenaran dan dan keadilan, dengan cara yang selurus-lurusnya. 
Terkait dengan hal itu, Undang-Undang Dasar 1945 yang telah diamandemen, tidak menghendaki adanya suatu lembaga negara tertentu yang memiliki kekuasaan yang tidak terkontrol, melainkan telah didisain di dalam suatu sistem dimana kekuasaan dipisahkan atau dibagi di dalam fungsi pada lembaga negara yang sederajat serta saling imbang dan saling mengawasi (checks and balances).

Undang-Undang Dasar 1945 yang telah diamandemen, telah mengintroduksi sebuah lembaga negara baru yang kewenangannya berkaitan dengan kekuasaan kehakiman yaitu Komisi Yudisial. Pengaturan mengenai Komisi Yudisial tersebut termaktub di dalam Pasal 24B Undang-Undang Dasar 1945, dimana konstitusi memberikan landasan hukum yang kuat bagi reformasi bidang hukum yakni dengan memberikan kewenangan kepada Komisi Yudisial untuk mewujudkan checks and balances.

Pelaksanaan checks and balances di bidang peradilan tersebut, diwujudkan melalui pemberian kewenangan kepada Komisi Yudisial untuk melaksanakan peran penting dalam usaha mewujudkan kekuasaan kehakiman yang merdeka melalui pencalonan hakim agung serta pengawasan terhadap hakim yang transparan dan partisipatif guna menegakkan kehormatan dan keluhuran martabat, serta menjaga perilaku hakim.

Berdasarkan amanat Undang-Undang Dasar 1945 di atas, kiranya dapat ditarik pengertian bahwa konstitusi menempatkan keberadaan hakim pada posisi terpenting dan paling menentukan keberhasilan penyelenggaraan kekuasaan kehakiman, karena hakimlah yang melakukan dan menjalankan kekuasaan kehakiman di lapangan penegakan hukum.

Oleh karenanya, diperlukan lembaga negara yang dapat menjamin bahwa hakim pada setiap tingkatan, dari hakim Pengadilan Negeri sampai hakim agung, memiliki integritas dan kepribadian yang tidak tercela, jujur, adil dan profesional. Dengan hakim yang demikian, diharapkan badan-badan peradilan mampu melaksanakan tugasnya dalam menegakkan hukum, keadilan dan kebenaran secara lurus dan benar serta terbebas dari praktik-praktik tidak terpuji bahkan melanggar hukum.

Sebaliknya, di tangan hakim yang memiliki kepribadian yang tercela, tidak memiliki integritas, kejujuran, keadilan dan keprofesionalan, hukum dibawa jauh dari keluhuran harkat dan martabat demi kebenaran dan keadilan. Hukum tidak lebih menjadi sekedar alat untuk memupuk kekayaan sehingga lingkungan peradilan yang 
semestinya menjadi benteng terakhir pemberantasan terhadap pelanggaran hukum (the last bastion of legal order) justeru berubah menjadi ladang suap menyuap dan pemufakatan jahat.

Dalam keadaan yang lebih buruk, tidak jarang terjadi perbuatan suap menyuap dan pemufakatan jahat itu dilakukan secara terencana dan terorganisir dengan melibatkan kekuatan uang dan kekuasaan yang demikian besar, sehingga lebih mirip dengan perbuatan mafia. Fenomena inilah yang kini sering dibicarakan sebagai mafia peradilan.

Pendapat mengenai mafia peradilan antara lain diungkapkan oleh Chandera bahwa :

Bentuk korupsi yang dikenal luas oleh masyarakat selain korupsi dilingkungan eksekutif dan legilslatif adalah korupsi di lingkungan yudikatif atau lembagalembaga peradilan atau lebih dikenal dengan mafia peradilan (judicial corruption). Maraknya korupsi di peradilan salah satunya disebabkan karena lemahnya pengawasan terhadap lembaga peradilan -baik pengawasan internal dari lembaga itu sendiri (internal control) maupun pengawasan eksternal dari luar lembaga tersebut (external control).... ${ }^{1}$

Berdasarkan paparan di atas, kiranya dapat ditarik pengertian bahwa secara konstitusional, lahirnya Komisi Yudisial dilatar-belakangi oleh kuatnya keinginan rakyat, yang disuarakan melalui gerakan reformasi untuk membersihkan hakim dan badan-badan dari praktik mafia peradilan. Karena praktik-praktik mafia peradilan tersebut, sudah menggurita dan bersifat sistemik, maka pembersihannya tidak mungkin lagi dilakukan oleh mekanisme pengawasan internal dengan cara-cara yang konvensional. Diperlukan cara pemberantasan yang bersifat "luar biasa", yang hanya bisa dilakukan oleh sebuah lembaga pengawasan eksternal yang bersifat independen dan kredibel.

Dengan demikian, jelaslah kiranya, betapa strategisnya amanat Konstitusi yang diletakkan di pundak Komisi Yudisial. Pemberantasan mafia peradilan, merupakan titik pangkal yang paling menentukan kualitas penegakan hukum, terutama penegakan hukum pidana.

${ }^{1}$ Chandera, dkk, "Modul Mata Kuliah Eksaminasi”, Fakultas Hukum Universitas Katolik Atma Jaya Yogyakarta, bekerjasama dengan Indonesia Corruption Watch, atas dukungan The Asia Foundation dan USAID, Desember 2004, hal. 2. 
Apabila dipandang dari perspektif hukum pidana, maka kebanyakan dari praktik-praktik mafia peradilan adalah perbuatan-perbuatan yang memenuhi unsur pidana, terutama perbuatan suap menyuap yang tergolong perbuatan pidana korupsi. Oleh karenanya, meskipun bukan berfungsi sebagai penegak hukum (pidana), keberadaan dan keberhasilan Komisi Yudisial dalam menjalankan kewenangannya, akan sangat berpengaruh pada penengakan hukum pidana yang diselenggarakan oleh sistem peradilan pidana Indonesia, terutama oleh sub sitem badan peradilan pidana.

Dalam peraturan perundang-undangan Indonesia, Komisi Yudisial diatur di dalam Undang-Undang Republik Indonesia Nomor 22 Tahun 2004 Tentang Komisi Yudisial (Selanjutnya disebut Undang-Undang Komisi Yudisial).

Menurut Undang-Undang yang disahkan di Jakarta pada tanggal 13 Agustus 2004 dan ditempatkan pada Lembaran Negara Republik Indonesia Tahun 2004 Nomor 89 tersebut, Komisi Yudisial dibentuk berdasarkan pertimbangan bahwa Komisi Yudisial mempunyai peranan penting dalam usaha mewujudkan kekuasaan kehakiman yang merdeka melalui pencalonan hakim agung serta pengawasan terhadap hakim yang transparan dan partisipatif guna menegakkan kehormatan dan keluhuran martabat, serta menjaga perilaku hakim.

Dalam Undang-Undang ini diatur secara rinci mengenai wewenang dan tugas Komisi Yudisial. Komisi Yudisial mempunyai tugas mengusulkan pengangkatan Hakim Agung dan wewenang lain dalam rangka menjaga dan menegakkan kehormatan, keluhuran martabat, serta perilaku hakim, yakni Hakim Agung dan hakim pada badan peradilan di semua lingkungan peradilan yang berada di bawah Mahkamah Agung serta Hakim Mahkamah Konstitusi sebagaimana dimaksud dalam UndangUndang Dasar Negara Republik Indonesia Tahun 1945.

Berkaitan dengan wewenang tersebut, dalam Undang-Undang ini juga diatur mengenai pengangkatan dan pemberhentian Anggota Komisi Yudisial. Syarat-syarat untuk diangkat menjadi Anggota Komisi Yudisial harus mempunyai pengetahuan dan pengalaman di bidang hukum serta memiliki integritas dan kepribadian yang tidak tercela. Anggota Komisi Yudisial ini diangkat dan diberhentikan oleh Presiden dengan persetujuan Dewan Perwakilan Rakyat.

Selain hal-hal yang ditentukan di atas, dalam Undang-Undang ini diatur pula mengenai larangan merangkap jabatan bagi Anggota Komisi Yudisial. Di samping itu 
diatur pula mengenai panitia seleksi untuk mempersiapkan calon Anggota Komisi Yudisial, beserta syarat dan tata caranya.

Wewenang dan tugas Komisi Yudisial diatur di dalam Bab III Pasal 13 Undang-Undang Komisi Yudisial, yang selengkapnya menyatakan bahwa :

Pasal 13

Komisi Yudisial mempunyai wewenang:

a. mengusulkan pengangkatan Hakim Agung kepada DPR; dan

b. menegakkan kehormatan dan keluhuran martabat serta menjaga perilaku hakim.

Sesuai dengan pokok bahasan dalam penelitian ini, maka wewenang yang akan dibahas adalah wewenang dari Komisi Yudisial yang kedua, yakni wewenang untuk menegakkan kehormatan dan keluhuran martabat serta menjaga perilaku hakim.

Berdasarkan ketentuan Pasal 13 Undang-Undang Komisi Yudisial tersebut di atas, kiranya dapat ditarik pengertian bahwa terdapat komitmen yang kuat dari negara untuk menciptakan suatu lembaga yang berfungsi sebagai pengawas dan penyeimbang, dimana dengan adanya lembaga tersebut proses penyelenggaraan peradilan oleh kekuasaan kehakiman yang merdeka dan bebas dari pengaruh kekuasaan lainnya, dapat dilaksanakan dengan selurus-lurusnya dan terbebas dari praktik-praktik mafia peradilan.

Mengacu pada paparan di atas, kiranya dapat ditarik benar merah yang dapat menggambarkan hubungan antara keberadaan Komisi Yudisial di satu sisi dengan Sistem Peradilan Pidana (SPP) Indonesia di sisi lainnya. Komisi Yudisial pada prinsipnya memang tidak terkait langsung dengan penyelenggaraan SPP Indonesia, namun demikian keberhasilan Komisi Yudisial menegakkan kehormatan dan keluhuran martabat serta menjaga perilaku hakim, akan menjamin terciptanya hakimhakim yang memiliki integritas dan kepribadian yang tidak tercela, jujur, adil dan profesional. Dengan memiliki hakim-hakim yang demikian, maka penegakan hukum melalui penyelesaian perkara pidana oleh SPP Indonesia, akan mencapai tujuannya secara optimal.

Untuk lebih memahami hubungan antara keberadaan Komisi Yudisial dengan SPP Indonesia, maka perlu ditinjau lebih jauh mengenai dengan wewenang Komisi Yudisial dalam menegakkan kehormatan dan keluhuran martabat serta menjaga perilaku hakim. 
Sehubungan dengan wewenang tersebut, Undang-Undang Komisi Yudisial menggariskan ketentuan mengenai tugas dari Komisi Yudisial di dalam Pasal 20 yang selengkapnya menyatakan bahwa:

Pasal 20

Dalam melaksanakan wewenang sebagaimana dimaksud dalam Pasal 13 huruf

b Komisi Yudisial mempunyai tugas melakukan pengawasan terhadap perilaku hakim dalam rangka menegakkan kehormatan dan keluhuran martabat serta menjaga perilaku hakim.

Dalam rangka pelaksanaan tugas melakukan pengawasan terhadap perilaku hakim, Undang-Undang Komisi Yudisial mengatur hak dan kewajiban dari Komisi Yudisial di dalam Pasal 22, yang menyatakan bahwa:

Pasal 22

(1) Dalam melaksanakan pengawasan sebagaimana dimaksud dalam Pasal 20, Komisi Yudisial:

a. menerima laporan masyarakat tentang perilaku hakim;

b. meminta laporan secara berkala kepada badan peradilan berkaitan dengan perilaku hakim;

c. melakukan pemeriksaan terhadap dugaan pelanggaran perilaku hakim;

d. memanggil dan meminta keterangan dari hakim yang diduga melanggar kode etik perilaku hakim; dan

e. membuat laporan hasil pemeriksaan yang berupa rekomendasi dan disampaikan kepada Mahkamah Agung dan/atau Mahkamah Konstitusi, serta tindasannya disampaikan kepada Presiden dan DPR.

(2) Dalam melaksanakan pengawasan sebagaimana dimaksud pada ayat (1), Komisi Yudisial wajib:

a. menaati norma, hukum, dan ketentuan peraturan perundang-undangan; dan

b. menjaga kerahasiaan keterangan yang karena sifatnya merupakan rahasia Komisi Yudisial yang diperoleh berdasarkan kedudukannya sebagai anggota.

(3) Pelaksanaan tugas sebagaimana dimaksud pada ayat (1) tidak boleh mengurangi kebebasan hakim dalam memeriksa dan memutus perkara. 
(4) Badan peradilan dan hakim wajib memberikan keterangan atau data yang diminta Komisi Yudisial dalam rangka pengawasan terhadap perilaku hakim dalam jangka waktu paling lambat 14 (empat belas) hari terhitung sejak tanggal permintaan Komisi Yudisial diterima.

(5) Dalam hal badan peradilan atau hakim tidak memenuhi kewajiban sebagaimana dimaksud pada ayat (4), Mahkamah Agung dan/atau Mahkamah Konstitusi wajib memberikan penetapan berupa paksaan kepada badan peradilan atau hakim untuk memberikan keterangan atau data yang diminta.

(6) Dalam hal badan peradilan atau hakim telah diberikan peringatan atau paksaan sebagaimana dimaksud pada ayat (5) tetap tidak melaksanakan kewajibannya, pimpinan badan peradilan atau hakim yang bersangkutan dikenakan sanksi sesuai dengan peraturan perundang-undangan di bidang kepegawaian.

(7) Semua keterangan dan data sebagaimana dimaksud pada ayat (4) bersifat rahasia.

(8) Ketentuan lebih lanjut mengenai tata cara pelaksanaan tugas sebagaimana dimaksud pada ayat (1) diatur oleh Komisi Yudisial.

Mengacu pada ketentuan mengenai hak dan kewajiban Komisi Yudisial tersebut, dapat ditarik kesimpulan bahwa dalam melaksanakan tugasnya mengawasi perilaku hakim khususnya menangani pelanggaran perilaku oleh seorang hakim yang diduga melanggar kode etik perilaku hakim, Komisi Yudisial, berhak menerima laporan masyarakat tentang perilaku hakim, dan memeriksa dugaan pelanggaran kode etik perilaku hakim dengan memanggil dan meminta keterangan atau memeriksa hakim bersangkutan.

Selanjutnya, apabila dari hasil pemeriksaan ditemukan bahwa dugaan pelanggaran kode etik perilaku hakim tersebut ternyata benar, Komisi Yudisial bertugas mengajukan usul penjatuhan sanksi terhadap hakim kepada pimpinan Mahkamah Agung dan/atau Mahkamah Konstitusi, sebagaimana diatur di dalam Pasal 21, yang menggariskan bahwa :

Pasal 21 
Untuk kepentingan pelaksanaan kewenangan sebagaimana dimaksud dalam Pasal 13 huruf b, Komisi Yudisial bertugas mengajukan usul penjatuhan sanksi terhadap hakim kepada pimpinan Mahkamah Agung dan/atau Mahkamah Konstitusi.

Berdasarkan ketentuan Pasal 21 dan 22 Undang-Undang Komisi Yudisial tersebut di atas, kiranya jelas bahwa tugas Komisi Yudisial melakukan pengawasan terhadap perilaku hakim dalam rangka menegakkan kehormatan dan keluhuran martabat serta menjaga perilaku hakim, menjadi selesai setelah mengajukan usul penjatuhan sanksi terhadap hakim kepada pimpinan Mahkamah Agung dan/atau Mahkamah Konstitusi, sebagaimana diatur di dalam Pasal 21 dan membuat laporan hasil pemeriksaan yang berupa rekomendasi dan disampaikan kepada Mahkamah Agung dan/atau Mahkamah Konstitusi, serta tindasannya disampaikan kepada Presiden dan DPR, sebagaimana diatur di dalam Pasal 22 Undang-Undang Komisi Yudisial.

Terhadap ketentuan tersebut, pertanyaan yang dapat diajukan adalah apakah dengan pembatasan kewenangan yang diberikan kepada Komisi Yudisial yakni sebatas menerima laporan masyarakat tentang perilaku hakim yang melanggar kode etik, dan melakukan pemeriksaan terhadap hakim yang diduga melakukan pelanggaran, dan kemudian membuat rekomendasi mengenai sanksi yang akan dijatuhkan kepada hakim yang berperilaku tidak terpuji tersebut tanpa kewenangan untuk melakukan penindakan, tujuan dibentuknya Komisi Yudisial yakni menjamin terciptanya hakim-hakim yang memiliki integritas dan kepribadian yang tidak tercela, jujur, adil dan profesional demi tegaknya hukum dan keadilan sebagaimana yang menjadi dasar pertimbangan lahirnya Komisi Yudisial akan dapat dicapai?..

\section{B. Perumusan Masalah}

Berdasarkan latar belakang yang telah penulis paparkan diatas, maka penulis merumuskan pokok permasalahan penelitian ini sebagai berikut:

1. Bagaimanakah Penegakan Kode Etik dan Pedoman Perilaku Hakim oleh Komisi Yudisial Dalam Rangka Pemberantasan Mafia Peradilan?;

2. Bagaimanakah Konsepsi Pembaharuan Hukum Mengenai Perluasan Kewenangan Komisi Yudisial Dalam Mengawasi Perilaku Hakim ?.

\section{Metode Penelitian}




\section{Metode Pendekatan}

Mengacu pada perumusan masalah dan tujuan penelitian tersebut di atas, maka penelitian ini dilakukan dengan menggunakan penelitian hukum normatif.. Penelitian hukum normatif mencakup penelitian terhadap asas-asas hukum, sistematika hukum, sinkronisasi hukum, perbandingan dan sejarah hukum.

Pendekatan yuridis normatif diambil sebagai pendekatan utama dalam penelitian ini karena yang menjadi perhatian utama adalah ketentuan perundangundangan yang mengatur mengenai kewenangan Komisi Yudisial dalam mengawasi perilaku hakim dalam kaitan dengan pemberantasan mafia peradilan.

\section{Pendekatan yang Digunakan}

Berdasarkan tipe penelitian normatif tersebut di atas, maka pendekatan yang digunakan dalam penelitian ini adalah pendekatan konseptual (conceptual approach), pendekatan perundang-undangan (normative approach) dan pendekatan sejarah (historical approach).

\section{Perluasan Kewenangan Komisi Yudisial Dalam Rangka Pemberantasan Praktik Mafia Peradilan}

1. Analisis Kewenangan Komisi Yudisial Dalam Mengawasi Perilaku Hakim Di Dalam Undang-Undang Komisi Yudisial

Penggunaan hukum tata negara sebagai kerangka analisis, sekilas mungkin tampak menyimpang dari bidang studi penulis, yakni hukum pidana. Namun keadaan sesungguhnya bukanlah demikian. Meski menggunakan kerangka hukum tata negara, tujuan pengkajian tetaplah diletakkan pada kepentingan penguatan hukum pidana.

Artinya, analisis mengenai kewenangan Komisi Yudisial, yang menjadi perhatian utama pada penelitian ini, semata ditujukan untuk memperkuat penegakan hukum melalui sistem peradilan pidana Indonesia, sedemikian sehingga sistem peradilan pidana Indonesia khususnya sub sistem pengadilan pidana, dapat menjadi pengadilan yang benar-benar bersih, berwibawa dan terbebas dari praktik-praktik mafia peradilan.

Dengan demikian, penulis berangkat dari asumsi bahwa kewenangan Komisi Yudisial menegakkan objektifitas kekuasaan kehakiman yang merdeka dengan membersihkan badan-badan peradilan dan korps hakim dari praktik-praktik tidak terpuji, merupakan proses penegakan hukum pidana yang paling strategis sifat dan dampaknya bagi masyarakat. 
Artinya, apabila dengan kewenangan yang tepat, Komisi Yudisial mampu menjadikan badan peradilan sebagai institusi penegak hukum yang berwibawa karena bersih dari praktik-praktik korupsi, maka penegakan hukum pidana akan menjadi lebih efektif. Efektifitas penerapan hukum pidana tersebut akan melahirkan kepastian hukum, keadilan dan kemanfaatan bagi masyarakat.

Selanjutnya, ia menjelaskan bahwa kewenangan atau wewenang adalah suatu istilah yang biasa digunakan dalam lapangan hukum publik. Namun sesungguhnya terdapat perbedaan diantara keduanya. Kewenangan adalah apa yang disebut "kekuasaan formal", kekuasaan yang berasal dari kekuasaan yang diberikan oleh Undang-undang atau legislatif. Sedangkan "wewenang" hanya merngenai suatu "onderdeel” (bagian) tertentu saja dari kewenangan.

Selanjutnya Sukamto Satoto berpendapat bahwa kewenangan diperoleh oleh seseorang atau sekolompok orang atau oleh suatu badan melalui 2 (dua) cara yaitu dengan atribusi atau dengan pelimpahan wewenang. Atribusi adalah wewenang yang melekat pada suatu jabatan. Dalam tinjauan hukum tata negara, atribusi ini ditunjukan dalam wewenang berdasarkan kewenangan yang dibentuk oleh pembuat undangundang. Atribusi ini menunjuk pada kewenangan asli atas dasar konstitusi (UUD) atau peraturan perundang-undangan.

Berdasarkan paparan diatas, maka kewenangan Komisi Yudisial yang ingin dikaji dalam penelitian ini adalah kewenangan atribusi yakni kewenangan yang dimiliki oleh Komisi Yudisial, yang diberikan oleh negara melalui Undang-Undang Dasar 1945 dan peraturan perundang-undangan, yakni Undang-undang Komisi Yudisial.

Sebagaimana telah dibahas dimuka bahwa negara melalui konstitusi, memberikan kewenangan kepada Komisi Yudisial, sebagaimana diamanatkan dalam Pasal 24B ayat (1) Undang-Undang Dasar 1945, yang selengkapnya menggariskan bahwa "Komisi Yudisial bersifat mandiri yang berwenang mengusulkan pengangkatan hakim agung dan mempunyai wewenang lain dalam rangka menjaga dan menegakkan kehormatan, keluhuran martabat, serta perilaku hakim".

Berdasarkan ketentuan Undang-Undang Dasar 1945 tersebut di atas, kiranya dapat dilihat dengan jelas komitmen yang kuat, tegas dan sungguh-sungguh dari negara untuk memberikan wewenang kepada Komisi Yudisial, dalam pengusulan 
pengangkatan hakim agung dan menjaga dan menegakkan kehormatan, keluhuran martabat, serta perilaku hakim.

Terhadap kewenangan sebagaimana ketentuan Pasal 24B tersebut, penulis berpendapat bahwa kewenangan tersebut adalah tergolong kewenangan penuh. Artinya, konstitusi member kewenangan penuh kepada Komisi Yudisial, dalam pengusulan pengangkatan hakim agung dan menjaga dan menegakkan kehormatan, keluhuran martabat, serta perilaku hakim.

Pendapat penulis tersebut didasarkan pada tidak adanya ketentuan di dalam Pasal 24B tersebut, yang menyatakan bahwa kewenangan Komisi Yudisial tersebut akan diatur melalui undang-undang. Dengan kata lain, tidak diperlukan ketentuan peraturan perundang-undangan untuk menafsirkan, menterjemahkan dan atau menginterpretasikan mengenai bentuk-bentuk kewenangan dari Komisi Yudisial, sebagaimana telah diatur di dalam Undang-Undang Dasar 1945.

Telah pula dibahas di muka, latar belakang yuridis historis lahirnya ketentuan Pasal 24B mengenai Komisi yudisial tersebut, yang pada pokoknya didasarkan pada keinginan yang kuat untuk menegakkan prinsip-prinsip kekuasaan kehakiman yang merdeka dan menjadikan badan-badan peradilan yang selama ini dikenal sarat dengan muatan korupsi, kolusi dan nepotisme $(\mathrm{KKN})$, menjadi benteng terakhir penegakan hukum (the last bastion of legal order) yang benar-benar bersih dan berwibawa.

Dengan demikian dalam bahasa yang lebih sederhana, kiranya dapat dikatakan bahwa dengan ketentuan Pasal 24B Undang-Undang Dasar 1945 tersebut, melalui kewenangan mengusulkan pengangkatan hakim agung dan menjaga dan menegakkan kehormatan, keluhuran martabat, serta perilaku hakim, Komisi Yudisial diberi kewenangan konstitusional oleh negara untuk membersihkan badan-badan peradilan sebagai pelaksana kekuasaan kehakiman pada setiap tingkatan dan pada setiap jenis peradilan, dari praktik-praktik mafia peradilan.

Pertanyaannya adalah apakah komitmen yang kuat, tegas dan sungguhsungguh dari negara untuk memberikan wewenang penuh kepada Komisi Yudisial untuk menegakkan prinsip-prinsip kekuasaan kehakiman yang merdeka dan menjadikan badan-badan peradilan menjadi benteng terakhir penegakan hukum yang benar-benar bersih dan berwibawa tersebut, telah diterjemahkan, dijabarkan dan atau diwujudkan dengan tepat dalam peraturan perundang-undangan. 
Sebagaimana telah dibahas sebelumnya bahwa dalam tataran peraturan perundang-undangan, Komisi Yudisial diatur di dalam Undang-Undang Komisi Yudisial. Di dalam Undang-Undang tersebut, wewenang dan tugas Komisi Yudisial diatur di dalam Bab III Pasal 13 Undang-Undang Komisi Yudisial, yang selengkapnya menyatakan bahwa :

Pasal 13

Komisi Yudisial mempunyai wewenang:

a. mengusulkan pengangkatan Hakim Agung kepada DPR; dan

b. menegakkan kehormatan dan keluhuran martabat serta menjaga perilaku hakim.

Terhadap ketentuan Pasal 13 Undang-Undang Komisi Yudisial tersebut di atas, penulis berpendapat bahwa terdapat relevansi yang kuat antara ketentuan yang mengatur mengenai kewenangan Komisi Yudisial di dalam Undang-Undang Dasar 1945 dengan Undang-Undang Komisi Yudisial.

Selanjutnya, untuk melaksanakan kewenangan khususnya wewenang menjaga kehormatan, keluhuran martabat dan perilaku hakim, Undang-Undang Komisi Yudisial menggariskan ketentuan mengenai tugas dari Komisi Yudisial di dalam Pasal 20 yang selengkapnya menyatakan bahwa:

Pasal 20

Dalam melaksanakan wewenang sebagaimana dimaksud dalam Pasal 13 huruf

b Komisi Yudisial mempunyai tugas melakukan pengawasan terhadap perilaku hakim dalam rangka menegakkan kehormatan dan keluhuran martabat serta menjaga perilaku hakim.

Dalam rangka pelaksanaan tugas melakukan pengawasan terhadap perilaku hakim, Undang-Undang Komisi Yudisial mengatur hak dan kewajiban dari Komisi Yudisial di dalam Pasal 22, yang menyatakan bahwa:

Pasal 22

(1) Dalam melaksanakan pengawasan sebagaimana dimaksud dalam Pasal 20, Komisi Yudisial:

a. menerima laporan masyarakat tentang perilaku hakim;

b. meminta laporan secara berkala kepada badan peradilan berkaitan dengan perilaku hakim;

c. melakukan pemeriksaan terhadap dugaan pelanggaran perilaku hakim; 
d. memanggil dan meminta keterangan dari hakim yang diduga melanggar kode etik perilaku hakim; dan

e. membuat laporan hasil pemeriksaan yang berupa rekomendasi dan disampaikan kepada Mahkamah Agung dan/atau Mahkamah Konstitusi, serta tindasannya disampaikan kepada Presiden dan DPR.

(2) Dalam melaksanakan pengawasan sebagaimana dimaksud pada ayat (1), Komisi Yudisial wajib:

a. menaati norma, hukum, dan ketentuan peraturan perundang-undangan; dan

b. menjaga kerahasiaan keterangan yang karena sifatnya merupakan rahasia Komisi Yudisial yang diperoleh berdasarkan kedudukannya sebagai anggota.

(3) Pelaksanaan tugas sebagaimana dimaksud pada ayat (1) tidak boleh mengurangi kebebasan hakim dalam memeriksa dan memutus perkara.

(4) Badan peradilan dan hakim wajib memberikan keterangan atau data yang diminta Komisi Yudisial dalam rangka pengawasan terhadap perilaku hakim dalam jangka waktu paling lambat 14 (empat belas) hari terhitung sejak tanggal permintaan Komisi Yudisial diterima.

(5) Dalam hal badan peradilan atau hakim tidak memenuhi kewajiban sebagaimana dimaksud pada ayat (4), Mahkamah Agung dan/atau Mahkamah Konstitusi wajib memberikan penetapan berupa paksaan kepada badan peradilan atau hakim untuk memberikan keterangan atau data yang diminta.

(6) Dalam hal badan peradilan atau hakim telah diberikan peringatan atau paksaan sebagaimana dimaksud pada ayat (5) tetap tidak melaksanakan kewajibannya, pimpinan badan peradilan atau hakim yang bersangkutan dikenakan sanksi sesuai dengan peraturan perundang-undangan di bidang kepegawaian.

(7) Semua keterangan dan data sebagaimana dimaksud pada ayat (4) bersifat rahasia.

(8) Ketentuan lebih lanjut mengenai tata cara pelaksanaan tugas sebagaimana dimaksud pada ayat (1) diatur oleh Komisi Yudisial. 
Mengacu pada ketentuan mengenai hak dan kewajiban Komisi Yudisial tersebut, dapat ditarik kesimpulan bahwa dalam melaksanakan tugasnya mengawasi perilaku hakim khususnya menangani pelanggaran perilaku oleh seorang hakim yang diduga melanggar kode etik perilaku hakim, Komisi Yudisial, berhak menerima laporan masyarakat tentang perilaku hakim, dan memeriksa dugaan pelanggaran kode etik perilaku hakim dengan memanggil dan meminta keterangan atau memeriksa hakim bersangkutan.

Mengacu pada ketentuan yang mengatur mengenai wewenang, tugas, hak dan kewajiban Komisi Yudisial di dalam Undang-Undang Komisi Yudisial tersebut di atas, penulis berkesimpulan bahwa kewenangan konstitusional Komisi Yudisial telah diterjemahkan dengan tepat oleh Undang-Undang Komisi Yudisial.

Selanjutnya, apabila dari hasil pemeriksaan ditemukan bahwa dugaan pelanggaran kode etik perilaku hakim tersebut ternyata benar, Komisi Yudisial bertugas mengajukan usul penjatuhan sanksi terhadap hakim kepada pimpinan Mahkamah Agung dan/atau Mahkamah Konstitusi, sebagaimana diatur di dalam Pasal 21, yang menggariskan bahwa :

Pasal 21

Untuk kepentingan pelaksanaan kewenangan sebagaimana dimaksud dalam Pasal 13 huruf b, Komisi Yudisial bertugas mengajukan usul penjatuhan sanksi terhadap hakim kepada pimpinan Mahkamah Agung dan/atau Mahkamah Konstitusi.

Ketentuan mengenai kewenangan Komisi Yudisial dalam mengawasi perilaku hakim sebagaimana diatur di dalam Pasal-pasal tersebut di atas, kemudian diatur tatacara pelaksanaannya di dalam Peraturan Komisi Yudisial Republik Indonesia Nomor 2 Tahun 2005 Tentang Tata Cara Pengawasan Hakim (selanjutnya Peraturan Komis Yudisial Tentang Tatacara Pengawasan Hakim).

Di dalam Peraturan yang disahkan di Jakarta tanggal 22 Agustus 2005 tersebut, termaktub sejumlah istilah penting yang relevan untuk diketahui, antara lain apa yang dimaksud sebagai laporan, temuan dan hakim yang menjadi objek pengawasan oleh Komisi Yudisial. Yang dimaksud dengan laporan adalah masalah-masalah yang disampaikan oleh masyarakat kepada Komisi Yudisial yang berisi dugaan pelanggaran kehormatan, keluhuran martabat serta perilaku hakim. 
Temuan adalah temuan Komisi Yudisial tentang data atau informasi yang didapat oleh Anggota Komisi Yudisial secara langsung maupun tidak langsung atas dugaan pelanggaran kehormatan, keluhuran martabat serta perilaku hakim.

Sementara yang dimaksud dengan Hakim yang menjadi objek pengawasan Komisi Yudisial adalah Hakim Agung dan hakim pada badan peradilan di semua lingkungan peradilan yang berada di bawah Mahkamah Agung serta Hakim Mahkamah Konstitusi sebagaimana dimaksud dalam Undang-Undang Dasar Negara Tahun 1945, termasuk hakim-hakim Ad Hoc.

Di dalam Peraturan Komisi Yudisial dimaksud terdapat sejumlah ketentuan penting menyangkut tatacara pengawasan hakim, antara lain ketentuan yang mengatur mengenai tata cara pemeriksaan, tata cara pengambilan keputusan dan bentuk-bentuk sanksi yang dapat dijatuhkan terhadap hakim yang terbukti bersalah melanggar kehormatan, keluhuran martabat dan perilaku hakim.

Tatacara Pemeriksaan diatur di dalam Bab IV Pasal 8 sampai dengan Pasal 11, yang pada pokoknya mengatur bahwa pemeriksaan dilakukan melalui pemeriksaan laporan dan/atau temuan tentang dugaan pelanggaran kehormatan, keluhuran martabat, serta perilaku hakim, pemeriksaan alat-alat bukti tertulis, mendengarkan keterangan pelapor/terlapor, keterangan saksi, keterangan ahli, pemeriksaan rangkaian data, keterangan, perbuatan, keadaan, dan/atau peristiwa yang bersesuaian dengan alat-alat bukti lain yang dapat dijadikan petunjuk, dan pemeriksaan alat-alat bukti lain yang berupa informasi yang diucapkan, dikirimkan, diterima, atau disimpan secara elektronik dengan alat optik atau yang serupa dengan itu.

Selanjutnya, badan peradilan atau hakim yang menjadi terlapor, memiliki sejumlah kewajiban sebagaiamana diatur di dalam Pasal 10, yang pada intinya menggariskan bahwa badan Peradilan dan hakim wajib memberikan keterangan atau data yang diminta Komisi Yudisial dalam jangka waktu paling lambat 14 (empat belas) hari terhitung sejak tanggal permintaan Komisi Yudisial.

Dalam hal badan peradilan atau hakim tidak memenuhi kewajiban, pimpinan Mahkamah Agung dan/atau pimpinan Mahkamah Konstitusi wajib memberikan penetapan berupa paksan kepada badan peradilan atau hakim untuk memberikan keterangan atau data yang diminta.

Dalam hal badan peradilan atau hakim telah diberikan peringatan berupa paksaan tetap tidak melaksanakan kewajibannya, pimpinan badan peradilan atau hakim 
yang bersangkutan dikenakan sanksi sesuai dengan peraturan perundang-undangan dibidang kepegawaian.

Sementara itu, mengenai tatacara pengambilan keputusan, diatur di dalam Bab V Pasal 12 dan 13 Peraturan Komis Yudisial Tentang Tatacara Pengawasan Hakim, yang pada pokoknya menggariskan bahwa "Pengambilan putusan dilakukan secara musyawarah untuk mencapai mufakat, apabila tidak tercapai, pengambilan putusan dilakukan dengan suara terbanyak. Apabila laporan diputuskan untuk tidak ditindak lanjuti, Sekretaris Jenderal memberitahukan kepada pelapor. Putusan rapat pleno disampaikan kepada pimpinan Mahkamah Agung atau pimpinan Mahkamah Konstitusi dalam bentuk Laporan Hasil Pemeriksaan, dengan tindasannya kepada Presiden dan Dewan Perwakilan Rakyat. Putusan rapat pleno setelah disampaikan kepada Mahkamah Agung atau Mahkamah Konstitusi, Presiden dan Dewan Perwakilan Rakyat, diumumkan kepada masyarakat. Apabila putusan rapat pleno menyatakan terlapor tidak bersalah melanggar kehormatan, keluhuran martabat serta perilaku hakim, maka Komisi Yudisial wajib memulihkan nama baiknya melalui media massa".

Adapun bentuk-bentuk sanksi yang dapat dijatuhkan terhadap hakim yang terbukti bersalah melanggar kehormatan, keluhuran martabat dan perilaku hakim, diatur di dalam Bab VI Sanksi Pasal 14, yang selengkapnya menggariskan bahwa:

Pasal 14

(1) Komisi Yudisial dalam rapat pleno berwenang menilai jenis dan kualitas pelanggaran terhadap kehormatan, keluhuran martabat serta perilaku hakim, dengan memperhatikan Kode Etik Hakim, dan menentukan jenis sanksi berdasarkan peraturan perundang-undangan;

(2) Jenis sanksi sebagaimana dimaksud pada ayat (1) berupa :

a. teguran tertulis;

b. pemberhentian sementara;

c. pemberhentian.

Mengacu pada ketentuan yang mengatur kewenangan Komisi Yudisial dalam menegakkan kehormatan, keluhuran martabat dan perilaku hakim di dalam UndangUndang Komisi Yudisial dan Peraturan Komis Yudisial Tentang Tatacara Pengawasan Hakim, sebagaimana yang telah dipaparkan di atas, kiranya dapat disimpulkan beberapa hal penting sebagai berikut: 
1. Wewenang, tugas, hak dan kewajiban Komisi Yudisial melakukan pengawasan terhadap perilaku hakim dalam rangka menegakkan kehormatan dan keluhuran martabat serta menjaga perilaku hakim, menjadi selesai setelah mengajukan usul penjatuhan sanksi terhadap hakim yang terbukti bersalah kepada pimpinan Mahkamah Agung dan/atau Mahkamah Konstitusi;

2. Tidak ada "daya paksa" bagi Komisi Yudisial untuk mengharuskan atau mewajibkan Mahkamah Agung dan atau Mahkamah Konstitusi untuk melaksanakan penjatuhan sanksi kepada hakim yang terbukti bersalah, sesuai dengan usul Komisi Yudisial.

Selanjutnya, perlu pula ditelusuri apakah Mahkamah Agung dan atau Mahkamah Konstitusi memiliki kewajiban untuk melaksanakan dan atau setidaknya mempertimbangkan rekomendasi yang disampaikan Komisi Yudisial tentang penjatuhan sanksi terhadap hakim yang terbukti melakukan pelanggaran terhadap kode etik dan pedoman perilaku hakim.

Penelusuran dilakukan terhadap Undang-Undang Kekuasaan Kehakiman, Undang-Undang Nomor 3 Tahun 2009 tentang Perubahan Kedua Undang-Undang Nomor 14 Tahun 1985 tentang Mahkamah Agung dan Undang-undang Nomor 24 Tahun 2003 tentang Mahkamah Konstitusi.

Setelah mencermati ketentuan di dalam Undang-Undang tersebut di atas, penulis berkesimpulan bahwa ketiga Undang-Undang tersebut telah mengatur mengenai keberadaan dan peran Komisi Yudisial sebagai pengawas eksternal dalam rangka menjaga dan menegakkan kehormatan, keluhuran martabat, serta perilaku hakim.

Namun demikian, ketiga Undang-Undang dimaksud sama sekali tidak mengatur tentang keberadaan hasil pemeriksaan eksternal yang dilakukan oleh Komisi Yudisial. Artinya, tidak ada kewajiban atau keharusan bagi Mahkamah Agung dan atau Mahkamah Konstitusi untuk melaksanakan atau setidaknya mempertimbangkan rekomendasi yang disampaikan oleh Mahkamah Konstitusi, terkait dengan pelanggaran kode etik dan pedoman perilaku hakim.

Berdasarkan kesimpulan tersebut di atas, kiranya menjadi jelas bahwa betapapun Komisi Yudisial sesuai dengan kewenangan yang ada padanya, telah bekerja keras melakukan pemeriksaan, mencari saksi, barang bukti dan alat bukti, sedemikian sehingga seorang hakim dinyatakan terbukti bersalah melakukan pelanggaran terhadap 
kehormatan, keluhuran martabat dan perilaku hakim, namun keputusan atau kekuasaan dan atau kewenangan untuk mengambil tindakan terhadap si hakim yang dinyatakan bersalah tersebut, tidak dimiliki oleh Komisi Yudisial.

Perlu atau tidaknya, bersalah atau tidaknya, dan dijatuhkan atau tidaknya sanksi kepada hakim yang menurut Komisi Yudisial telah nyata bersalah itu, tergantung pada kehendak atau kemauan atau goodwill dari Mahkamah Agung dan atau Mahkamah Konsitusi.

Artinya, betapapun menurut Komisi Yudisial, seorang hakim dinyatakan terbukti bersalah, apabila Mahkamah Agung dan atau Mahkamah Konstitusi, menurut standar, kriteria, tafsiran atau interpretasinya, menganggap perbuatan si hakim itu bukan perbuatan yang termasuk pelanggaran terhadap kehormatan, keluhuran martabat dan perilaku hakim, maka tidak akan pernah ada tindakan apapun terhadap si hakim itu.

Citra peradilan kita masih merah. Mafia peradilan sudah berjalan secara sangat sistemik, sehingga diperlukan cara-cara pemberantasan yang juga bersifat sistemik. Hakim itu ujung tombak pencari keadilan, nasib sebuah perkara akan berujung pada hakim yang menangani perkara. Ia yang memutus dan menentukan perkara siapa yang salah dan siapa yang benar. Kalau moralitasnya buruk maka usaha menciptakan keadilan akan gagal. Kalau hakim yang menjadi kepanjangan tangan dalam menciptakan keadilan mengabaikan azas etika maupun disiplin korpsnya, nasib penanganan perkara akan jauh dari apa yang diharapkan oleh para pencari keadilan. Disinilah letak peran Komisi Yudisial. Namun, dengan kewenangan sebagaimana diatur di dalam UndangUndang Komisi Yudisial, ruang gerak Komisi Yudisial untuk melakukan pemberantasan mafia peradilan, diakui sangatlah sempit dan terbatas.

Terhadap laporan masyarakat yang masuk, Komisi Yudisial telah menunjukkan kinerja yang cukup baik. Hal itu terlihat dari besarnya jumlah hakim yang berhasil diperiksa, dan jumlah hakim yang dinyatakan terbukti bersalah setelah menjalani pemeriksaan, sesuai dengan ketentuan mengenai tatacara pemeriksaan sebagaimana diatur di dalam Peraturan Komisi Yudisial tentang Tatacara Pengawasan hakim.

Persoalan pengawasan terhadap perilaku hakim kemudian muncul, manakala Komisi Yudisial mengajukan usulan penjatuhan sanksi terhadap hakim-hakim yang dinyatakan terbukti bersalah telah melanggar kehormatan, keluhuran martabat dan perilaku hakim. 
Penulis berpendapat bahwa, lemahnya kinerja pengawasan dan penindakan terhadap hakim dengan perilaku yang menyimpang tersebut, lebih banyak disebabkan oleh kelemahan perumusan kewenangan Komisi Yudisial di dalam Undang-Undang Komisi Yudisial.

Undang-Undang Komisi Yudisial khususnya ketentuan Pasal 21 dan tatacara pelaksanaan pengawasan hakim sebagaimana diatur di dalam Peraturan Komisi Yudisial, telah secara nyata mereduksi (mengurangi dan menyempitkan) kewenangan Komisi Yudisial dari kewenangan yang bersifat penuh dalam Undang-Undang Dasar 1945, menjadi kewenangan yang sempit dan terbatas yakni sebatas menerima laporan, memeriksa dan mengusulkan penjatuhan sanksi.

Berdasarkan paparan di atas, kiranya sudah dapat diperoleh jawaban terhadap permasalahan pertama dalam penelitian ini, bahwa ditinjau dari amanat Pasal 24B Undang-Undang Dasar 1945, Undang-Undang Komisi Yudisial belum memuat ketentuan yang jelas dan tegas tentang kewenangan Komisi Yudisial dalam mengawasi perilaku Hakim. Kewenangan Komisi Yudisial yang semestinya menurut UndangUndang Dasar 1945 bersifat kewenangan penuh, justeru direduksi menjadi kewenangan yang bersifat terbatas dan sempit oleh Undang-Undang Komisi Yudisial.

\section{Konsepsi Pembaharuan Hukum Mengenai Perluasan Kewenangan Komisi Yudisial} Dalam Mengawasi Perilaku Hakim

Sebagaimana telah dibahas pada bagian sebelumnya, bahwa rendahnya kinerja penegakan hukum baik hukum administrasi maupun pidana, terhadap hakim yang terbukti melakukan pelanggaran terhadap kehormatan, keluhuran martabat dan perilaku hakim, lebih banyak disebabkan oleh reduksi kewenangan konstitusional Komisi Yudisial oleh Undang-Undang Komisi Yudisial.

Reduksi kewenangan tersebut, tentu saja menimbulkan sejumlah pertanyaan. Pertanyaan paling sederhana yang dapat diajukan adalah kalau hanya sebatas menerima laporan, memeriksa dan mengusulkan penjatuhan sanksi, sementara usulan tersebut tidak memiliki kepastian akan dilaksanakan atau tidak, lalu untuk apa negara susahsusah merumuskan keberadaan Komisi Yudisial dalam konstitusi negara?.

Tidakkah lebih baik urusan pengawasan perilaku hakim diserahkan saja pada satuan pengawasan internal (internal control unit) yang selama ini sudah ada pada 
Mahkamah Agung. Toh kalau sekedar menerima laporan, memeriksa dan mengusulkan penjatuhan sanksi, satuan pengawasan internal tersebut "sudah biasa" melakukannya?.

Lagipula, bukankah di dalam Undang-Undang Kekuasaan Kehakiman, UndangUndang Mahkamah Agung dan Undang-Undang Mahkamah Konstitusi, telah diatur mengenai mekanisme atau tatacara penjatuhan sanksi terhadap hakim yang melakukan pelanggaran kode etik dan panduan perilaku hakim?

Bukankah di dalam ketiga Undang-Undang tersebut, telah ditegaskan pula bahwa penjatuhan sanksi terhadap hakim, tunduk pada Undang-Undang yang mengatur tentang kepegawaian, lalu mengapa harus ada Komisi Yudisial, kalau hanya untuk sekedar menerima laporan masyarakat, memeriksa dan mengusulkan penjatuhan sanksi saja?.

Pertanyaan berikutnya adalah, manakala hanya diberi kewenangan yang terbatas, tanpa ada jaminan bahwa pelaksanaan kewenangan tersebut akan memiliki kekuatan hukum dan daya paksa, tidakkah kewenangan tersebut serta merta akan menjadi proses penegakan hukum yang justeru menimbulkan ketidak-adilan, tidak membawa kepastian hukum dan kemanfaatan hukum apapun, bagi masyarakat?

Apabila demikian halnya, tidakkah perumusan kewenangan Komisi Yudisial di dalam Undang-Undang Komisi Yudisial, yang tidak lebih dari sekedar "wajah” baru dari satuan pengawasan internal Mahkamah Agung, merupakan pengingkaran terhadap latar belakang konstitusional dibentuknya Komis Yudisial, dimana Komisi Yudisial dibentuk untuk memberantas "penyimpangan luar biasa" yang terjadi dalam badanbadan peradilan, yang tidak mungkin bisa diatasi dengan cara-cara yang konvensional.

Bila demikian, bagaimana mungkin Komisi Yudisial, diharapkan akan mampu mengemban amanat Undang-Undang Dasar 1945 untuk memperkuat proses penegakan hukum dengan menegakkan prinsip-prinsip kekuasaan kehakiman yang merdeka, dan membebaskan badan peradilan dari praktik-praktik mafia peradilan?.

Mengenai tujuan penegakan hukum, kiranya relevan untuk mengingat kembali apa yang dikatakan oleh seorang pemikir hukum, Gustav Radbruch. Ia seperti dikutip Bernard Arief Sidharta, mengatakan bahwa hukum berfungsi sebagai perlindungan kepentingan manusia. Agar kepentingan manusia terlindungi, hukum harus dilaksanakan. Pelaksanaan hukum dapat berlangsung secara normal, damai tetapi dapat terjadi juga karena pelanggaran hukum. Dalam hal ini hukum yang telah dilanggar itu harus ditegakkan, Melalui penegakan hukum inilah hukum menjadi kenyataan. Dalam 
menegakkan hukum ada tiga unsur yang selalu harus diperhatikan, yaitu : kepastian hukum (rechtssichherheit), kemanfaatan (zweckmaasigkeit) dan keadilan (gereichtigkeit). ${ }^{2}$

Berdasarkan pendapat ahli hukum tersebut di atas, penulis berpendapat bahwa dikaitkan dengan pengaturan mengenai kewenangan Komisi Yudisial dalam mengawasi perilaku hakim, maka diperlukan cara pandang yang jauh lebih komprehensif dalam menentukan kewenangan yang bagaimana yang semestinya diberikan kepada Komisi Yudisial.

Dengan demikian, manakala kita menginginkan keberadaan Komisi Yudisial yang berwibawa, maka pemberian kewenangan kepada Komisi itu, haruslah mampu memenuhi tujuan penegakan hukum yakni menciptakan rasa keadilan, kepastian hukum dan membawa kemanfaatan hukum bagi masyarakat.

Berdasarkan pendapat yang dikemukakan di atas, dan demi mengingat pentingnya keberadaan ketentuan yang mengatur tentang kewenangan Komisi Yudisial bagi terbentuknya badan peradilan yang bersih dan berwibawa, maka menurut hemat penulis sudah sangat mendesak kiranya, untuk merumuskan secara lebih komprehensif, kewenangan Komisi Yudisial dalam mengawasi perilaku hakim di dalam UndangUndang Komisi Yudisial.

Alasan yang mendasari pendapat penulis adalah bahwa apabila pengaturan mengenai kewenangan Komisi Yudisial dalam mengawasi perilaku hakim di dalam Undang-Undang Komisi Yudisial yang berlaku saat ini tidak dirubah, maka kita telah membiarkan Komisi Yudisial bagaikan seekor macan kertas yang kehadirannya sama sekali tidak dianggap dan ditakuti.

Dalam keadaan yang demikian, keberadaan Komisi Yudisial cenderung tidak akan membawa dampak apapun bagi pencegahan dan pemberantasan perilaku hakim yang tidak terpuji, terutama perilaku yang menyuburkan tindak pidana korupsi yang terjadi pada badan-badan peradilan, yang dari waktu ke waktu justeru makin marak dan merajalela.

Sebaliknya, kita sangat berkepentingan untuk membuat Komisi Yudisial mampu bertindak bagaikan seekor macan ganas yang memiliki taring tajam sehingga ditakuti dan atau memiliki kewibawaan hukum dalam memberangus setiap perilaku 190.

${ }^{2}$ Bernard Arief Sidharta, Refleksi tentang Struktur Ilmu Hukum, Mandar Maju, Bandung, , hal. 
menyimpang, terutama perbuatan korupsi pada badan peradilan, dalam skala dan dampak yang makin serius.

Oleh karena itu, penulis berpendapat bahwa diperlukan perluasan kewenangan Komisi Yudisial dalam Undang-Undang Komisi Yudisial, sedemikian sehingga Komisi Yudisial memperoleh kewenangan yang lebih bersifat komprehensif, dalam menjaga kehormatan, keluhuran martabat dan perilaku hakim serta mengambil tindakan terhadap hakim yang terbukti melanggar kode etik dan pedoman perilaku hakim.

Dengan perkataan lain, kita perlu mengembalikan kewenangan Komisi Yudisial yang saat ini bersifat terbatas menjadi kewenangan penuh dalam mengusulkan pengangkatan hakim agung, menjaga dan menegakkan kehormatan, keluhuran martabat, serta perilaku hakim, sebagaimana yang dikehendaki oleh Undang-Undang Dasar 1945.

Penulis berpendapat bahwa yang dimaksud dengan wewenang penuh dalam menjaga dan menegakkan kehormatan, keluhuran martabat, serta perilaku hakim, adalah bahwa Komisi Yudisial dengan kewenangan yang ada padanya, bertanggungjawab secara penuh dalam menjaga dan menegakkan kehormatan, keluhuran martabat, serta perilaku hakim. Di pundak Komisi Yudisiallah diletakkan tanggungjawab untuk memastikan bahwa badan peradilan benar-benar diisi dan dijalankan oleh hakim-hakim yang meletakkan kehormatan dan keluhuran martabatnya sebagai hakim, di atas segala-galanya.

Dengan tanggungjawab penuh semacam itu, maka apabila terjadi pelanggaran terhadap kehormatan, keluhuran martabat dan perilaku hakim, atau pelanggaran terhadap kode etik dan perilaku hakim, maka seyogyanyalah Komisi Yudisial tidak hanya berwenang menerima laporan, memeriksa dan mengusulkan penjatuhan sanksi saja, melainkan harus diberi wewenang penuh untuk mengambil tindakan berupa penjatuhan sanksi terhadap hakim yang terbukti bersalah, sesuai dengan tingkat kesalahan dari hakim bersangkutan.

Dengan demikian, kiranya menjadi jelas bahwa kewenangan penuh yang dimaksudkan adalah kewenangan Komisi Yudisial dalam menjaga dan menegakkan kehormatan, keluhuran martabat, serta perilaku hakim dalam arti yang sebenarbenarnya, yakni mulai dari pencegahan (agar hakim tidak melanggar kehormatan dan keluhuran martabatnya sebagai hakim), sampai dengan penindakan terhadap hakim- 
hakim yang terbukti bersalah melakukan tindakan tidak terpuji, yang bertentangan kode etik dan pedoman perilaku hakim.

Dengan kewenangan yang bersifat komprehensif yang meliputi kewenangan pencegahan dan penindakan tersebut, penulis yakin dan percaya bahwa Komisi Yudisial akan menjadi institusi pengawasan hakim dan badan peradilan yang berwibawa dan disegani. Komisi Yudisial yang memiliki wewenang untuk bertindak tegas dan keras, akan membuat hakim-hakim merasa takut untuk melakukan perbuatanperbuatan yang melanggar kode etik dan pedoman perilaku hakim.

Keadaan tersebut pada gilirannya akan melahirkan budaya anti korupsi dan anti pelanggaran kode etik di kalangan hakim dan badan peradilan dan bermuara pada tegaknya prinsip-prinsip kekuasaan kehakiman yang merdeka, yang berwibawa dan bersih dari praktik-praktik mafia peradilan.

Berdasarkan paparan di atas, maka penulis mengajukan konsepsi pembaharuan hukum mengenai perluasan kewenangan Komisi Yudisial dalam mengawasi perilaku hakim, melalui amandemen atau perubahan Undang-undang Komisi Yudisial, sebagai berikut:

1. Memperbaiki dan atau menyempurnakan dan atau menambah rumusan ketentuan Pasal 20 Undang-Undang Komisi Yudisial dari semula :

Dalam melaksanakan wewenang sebagaimana dimaksud dalam Pasal 13 huruf b Komisi Yudisial mempunyai tugas melakukan pengawasan terhadap perilaku hakim dalam rangka menegakkan kehormatan dan keluhuran martabat serta menjaga perilaku hakim.

\section{Menjadi:}

Dalam melaksanakan wewenang sebagaimana dimaksud dalam Pasal 13 huruf b Komisi Yudisial mempunyai tugas melakukan pengawasan terhadap perilaku hakim dalam rangka menegakkan kehormatan dan keluhuran martabat serta menjaga perilaku hakim, dan menjatuhkan sanksi sesuai dengan ketentuan perundang-undangan terhadap hakim yang terbukti bersalah melanggar kode etik dan pedoman perilaku hakim.

2. Mencabut ketentuan Pasal 21 Undang-Undang Komisi Yudisial; 
3. Mengganti rumusan Pasal 22 ayat (1) huruf e Undang-Undang Komisi Yudisial dari semula :

Membuat laporan hasil pemeriksaan yang berupa rekomendasi dan disampaikan kepada Mahkamah Agung dan/atau Mahkamah Konstitusi, serta tindasannya disampaikan kepada Presiden dan DPR.

\section{Menjadi:}

Menjatuhkan sanksi sesuai dengan ketentuan perundang-undangan terhadap hakim yang terbukti bersalah melanggar kode etik dan pedoman perilaku hakim.

Berdasarkan konsepsi pembaharuan hukum terhadap kewenangan Komisi Yudisial yang diajukan di atas, kiranya menjadi jelas bahwa Ketentuan yang sebaiknya diterapkan agar kewenangan Komisi Yudisial dalam mengawasi perilaku hakim mampu mendukung tujuan penyelenggaraan peradilan pidana yakni tercapainya penegakan hukum dan keadilan melalui SPP Indonesia, adalah memberikan kewenangan penuh kepada Komisi Yudisial, sedemikian rupa sehingga Komisi Yudisial tidak saja berwenang melakukan pencegahan agar hakim tidak melanggar kode etik dan pedoman perilaku hakim, melainkan juag berwenang melakukan penindakan terhadap hakim yang terbukti bersalah, dengan menjatuhkan sanksi, sesuai dengan ketentuan perundangundangan, mulai dari teguran tertulis sampai dengan pemberhentian.

Konsepsi mengenai kewenangan Komisi Yudisial yang bersifat kewenangan penuh yang penulis ajukan di atas, sesungguhnya bukanlah konsepsi hukum yang baru, karena telah banyak diterapkan pada Komisi Yudisial di sejumlah negara, antara lain Argentina, Thailand, Afrika Selatan, Sierra Leone dan Italia.

Menurut A. Ahsin Thohari, Komisi Yudisial di Argentina bernama Council of Magistracy yang diatur di dalam Article 114 Konstitusinya. Argentina. Dewan ini berfungsi mengajukan calon hakim agung kepada Senat dan diangkat oleh Presiden, bertanggung jawab terhadap seleksi hakim dan administrasi kekuasaan kehakiman, mengembangkan pemilihan kandidat hakim tingkat bawah melalui kompetisi publik, mengeluarkan usulan tiga nama kandidat hakim tingkat bawah, mengurus sumber daya untuk administrasi pengadilan, melakukan tindakan pendisiplinan terhadap hakim, 
memutuskan pemberhentian hakim, dan mengeluarkan peraturan tentang organisasi pengadilan untuk menjamin independensi hakim dan efisiensi administrasi pengadilan. ${ }^{3}$

Negara lain yang memberi kewenangan penuh kepada Komisi Yudisial adalah Thailand. Di Thailand, Komisi Yudisial bernama Judicial Commission of the Court of Justice yang diatur di dalam beberapa pasal Konstitusinya. Komisi ini berfungsi memberikan persetujuan pengangkatan dan pemberhenti-an Hakim Agung sebelum diajukan kepada Raja, dan memberikan persetujuan tentang romosi, kenaikan gaji dan menghukum Hakim Agung. ${ }^{4}$

Selanjutnya adalah Afrika Selatan. Komisi Yudisial di Afrika Selatan bernama Judicial Service Commission yang diatur di dalam Section 174 Konstitusinya. Komisi ini berfungsi memberikan advis kepada Presiden dalam pengangkatan dan pemberhentian Ketua dan Wakil Ketua Mahkamah Konstitusi, Ketua dan Wakil Ketua Mahkamah Agung, dan hakim di semua lembaga peradilan.

Komisi Yudisial di Sierra Leone bernama Judicial and Legal Service Commission. Komisi ini berfungsi memberikan advis kepada Ketua Mahkamah Agung dalam penyelenggaraan fungsi-fungsi administratif dan lain-lain, mengangkat, mempromosikan, memutasikan, memberhentikan, dan mendisiplinkan orang-orang yang menduduki jabatan kehakiman.

Sementara itu di Italia, Komisi Yudisial bernama The Superior Council of the Judiciary yang diatur di dalam Section 105 Konstitusinya. Komisi ini mempunyai hak mengangkat, memberhentikan, memutasikan, dan mempromosikan anggota badan peradilan dan memberikan tindakan pendisiplinan terhadapnya.

Mengacu pada paparan di atas, dapatlah diambil kesimpulan akhir pada bagian ini bahwa agar Komisi Yudisial mampu mengemban wewenang konstutusionalnya, membersihkan hakim dan badan peradilan dari praktik-praktik mafia peradilan, maka sudah mendesak kiranya untuk melakukan amandemen atau perubahan terhadap UndangUndang Komisi Yudisial, terutama menyangkut ketentuan mengenai wewenang mengawasi perilaku hakim dalam rangka menegakkan kehormatan, keluhuran martabat dan perilaku hakim.

\footnotetext{
${ }^{3}$ A. Ahsin Thohari, Op. Cit., hal. 36-38

${ }^{4}$ Ibid.

${ }^{5}$ Ibid.

${ }^{6}$ Ibid.

${ }^{7}$ Ibid.
} 


\section{E. Kesimpulan}

Berdasarkan uraian pada bab terdahulu, maka dapat diambil beberapa kesimpulan sebagai berikut :

1. Ditinjau dari amanat Pasal 24B Undang-Undang Dasar 1945, Undang-Undang Komisi Yudisial belum memuat ketentuan yang jelas dan tegas tentang kewenangan Komisi Yudisial dalam mengawasi perilaku Hakim. Kewenangan Komisi Yudisial yang semestinya menurut Undang-Undang Dasar 1945 bersifat kewenangan penuh, justeru direduksi oleh Undang-Undang Komisi Yudisial menjadi kewenangan yang bersifat terbatas dan sempit, sebatas menerima laporan masyarakat, memeriksa hakim yang diduga bermasalah dan mengajukan usulan penjatuhan sanksi bagi hakim yang terbukti melanggar kode etik dan pedoman perilaku hakim. Kewenangan yang terbatas tersebut telah menyebabkan ketidakmampuan Komisi Yudisial mengemban wewenang konstutusionalnya, membersihkan hakim dan badan peradilan dari praktik-praktik mafia peradilan;

2. Ketentuan yang sebaiknya diterapkan agar ketentuan mengenai kewenangan Komisi Yudisial dalam mengawasi perilaku hakim mampu mendukung tujuan penyelenggaraan peradilan yakni tercapainya penegakan hukum dan keadilan melalui SPP Indonesia, adalah memberikan kewenangan penuh kepada Komisi Yudisial, sedemikian rupa sehingga Komisi Yudisial tidak saja berwenang melakukan pencegahan agar hakim tidak melanggar kode etik dan pedoman perilaku hakim, melainkan juga berwenang melakukan penindakan terhadap hakim yang terbukti bersalah, dengan menjatuhkan sanksi, sesuai dengan ketentuan perundang-undangan, mulai dari teguran tertulis sampai dengan pemberhentian.

\section{F. Rekomendasi}

1. 1. Agar Kode Etik dapat dijadikan suatu Peraturan bukan hanya Pedoman sehingga dapat diperlakukan secara efektif. Kalau hanya kode etik saja kurang efektif. Ketidak efektifan Komisi Yudisial ini tidak cukup hanya masalah Undangundang saja namun harus dijalankan juga bahwa Komisi Yudisial bagian dari Mahkamah Agung.

2. Konsepsi pembaharuan hukum ketentuan mengenai kewenangan Komisi Yudisial dalam mengawasi perilaku hakim yang diajukan adalah : 
a. Memperbaiki dan atau menyempurnakan dan atau menambah rumusan ketentuan Pasal 20 Undang-Undang Komisi Yudisial dari semula :

Dalam melaksanakan wewenang sebagaimana dimaksud dalam Pasal 13 huruf b Komisi Yudisial mempunyai tugas melakukan pengawasan terhadap perilaku hakim dalam rangka menegakkan kehormatan dan keluhuran martabat serta menjaga perilaku hakim.

\section{Menjadi:}

Dalam melaksanakan wewenang sebagaimana dimaksud dalam Pasal 13 huruf b Komisi Yudisial mempunyai tugas melakukan pengawasan terhadap perilaku hakim dalam rangka menegakkan kehormatan dan keluhuran martabat serta menjaga perilaku hakim, dan menjatuhkan sanksi sesuai dengan ketentuan perundang-undangan terhadap hakim yang terbukti bersalah melanggar kode etik dan pedoman perilaku hakim.

b. Mencabut ketentuan Pasal 21 Undang-Undang Komisi Yudisial;

c. Mengganti rumusan Pasal 22 ayat (1) huruf e Undang-Undang Komisi Yudisial dari semula :

Membuat laporan hasil pemeriksaan yang berupa rekomendasi dan disampaikan kepada Mahkamah Agung dan/atau Mahkamah Konstitusi, serta tindasannya disampaikan kepada Presiden dan DPR.

\section{Menjadi:}

Menjatuhkan sanksi sesuai dengan ketentuan perundang-undangan terhadap hakim yang terbukti bersalah melanggar kode etik dan pedoman perilaku hakim.

\section{G. Daftar Pustaka}

Chandera, dkk, "Modul Mata Kuliah Eksaminasi", Fakultas Hukum Universitas Katolik Atma Jaya Yogyakarta, bekerjasama dengan Indonesia Corruption Watch, atas dukungan The Asia Foundation dan USAID, Desember 2004

Sukamto Satoto, Pengaturan Eksistensi dan fungsi Badan Kepegawaian Negara, CV Hanggar Kreator, Jogjakarta, 2004

Abdul latif, Hukum dan Peraturan Kebijaksanaan (Beleidregel) pada Pemerintahan Daerah, UII Press, Jogjakarta, 2005

Bernard Arief Sidharta, Refleksi tentang Struktur Ilmu Hukum, Mandar Maju, Bandung, 